\title{
COAL TAR VISCOSITY WHEN DISSOLVING COKE OVEN GAS DEPOSITS
}

\author{
Oleksandr Pasternak ${ }^{1}$, Leonid Bannikove, ${ }^{2}$, Anna Smirnova²
}

DOI: dx.doi.org/10.23939/chcht11.01.125

\begin{abstract}
The data on the viscosity of the tar when dissolving non-substituted aromatic compounds (naphthalene and anthracene) were received. The viscosity coefficients of available empirical equations when adding the naphthalene and anthracene were determined. The rheological properties of the tar on a Brookfield viscometer were investigated with imitative additives. Irregular values of energy activation of viscous flow were established with the additive of certain amount of naphthalene that also correlated with the minimum value of the constant $\mathrm{K} 2$ of Walter equation and constant $\mathrm{B}$ in the equation of CornelissenWaterman. The above data allow to recommend the temperature ranges and optimal amount of naphthalene for obtaining coal tar with improved rheological properties.
\end{abstract}

Keywords: coking production, gas collecting main, primary cooler, coal tar viscosity.

\section{Introduction}

Coking volatile products are the carrier of all the vapor and gaseous materials formed during the coking process and then recovered and processed into chemical products. Some condensed aromatic compounds sublime and form deposits while moving on coking volatile products path, creating a certain pressure drop.

To eliminate the deposits a washing process of gas equipment is used, beginning with gas collecting main and primary coolers and ending with gas aqueous washing before the combustion for heating of coke oven batteries. Condensation of tar and water vapors from the coke oven gas has a tendency to reduce deposits formation or, to some extent, to dissolve crystals formed mainly from naphthalene.

\footnotetext{
${ }^{1}$ PJSC "AVDIIVKA COKE"

1, Industrialnyi Proezd, 86065 Avdiivka, Ukraine

${ }^{2}$ Ukrainian State Research Institute of Carbochemistry (UKHIN)

7, Vesnina St., 61023 Kharkiv, Ukraine

*ukhinbannikov@gmail.com

(c) Pasternak O., Bannikov L., Smirnova A., 2017
}

Therefore, specially organized coke oven gas washing process is based on the most accessible medium coal tar or water. Coal tar has an advantage of its high solving ability of naphthalene, theoretical solubility of which in tar can be estimated by the equation of Schroeder-Le Chatelier [1].

Tar condenses from coke oven gas twice: at a relatively high temperature of $348-368 \mathrm{~K}$ in gas collecting main and at low temperature of $298-313 \mathrm{~K}$ in primary gas coolers. This results in formation of two wash media having a certain degree of alternative properties. In the first case tar from collecting main has low naphthalene content $\quad(\approx 7 \%)$, high dissolving ability toward naphthalene but increased viscosity. In the second case tar from primary coolers has alternative properties i.e. low viscosity and low dissolving ability toward naphthalene (naphthalene content $\approx 18 \%$ ).

One of the main problems of gas equipment washing consists in selecting the most suitable type of tar, or in the preparation of the required quality of the tars mixture. Characteristics of tars from collecting main and primary coolers was investigated at different times [2, 3], and in our opinion, not so fully. It may be explained probably due to necessity of tars mixing, which favorably influences decantation of water and solids from the more viscous tar emulsion from collecting main. Different pyrolysis degree and various proportions between the condensation temperatures of tars in various plants leads to individual tars characteristics, which makes it difficult to classify them. In our opinion, it is necessary to obtain data on the rheological properties of the tars concerning to dissolving ability towards coke oven gas deposits. This data will allow forming a washing liquid (coal tar water emulsion) with optimum properties for effective naphthalene dissolution. Increasing the tar viscosity in washing process can lead to formation of a thick organic hydrocarbon layer on the surface of cooler's pipe, which reduces the heat transfer coefficient in the apparatus.

To control tar viscosity changes when dissolving non-substituted aromatic compounds forming deposits in 
liquid for gas space washing in the process of cooling and condensation of coking volatile products it is necessary:

- to improve the existing empirical formulas of tar viscosity for predicting the rheological characteristics of liquids for gas apparatus washing;

- to determine the optimal content of the most representative non-substituted aromatic compounds in the washing liquid affecting tar viscosity.

\section{Experimental}

As the object of study a high pyrolysis degree coal tar from primary cooler was selected, the density of which could be quite equal to value of tar from collecting main with low degree of pyrolysis. This type of coal tar is the most characteristic of liquid on which an emulsion for washing the gas space of the coke oven gas primary coolers is formed. The tar properties are shown in Table 1.

The viscosity of the tar was measured in the temperature range of $313-353 \mathrm{~K}$ by rotary viscometer Brookfield DV2T with a thermocell at the shear rate of $186 \mathrm{~s}^{-1}$. As the additives crystalline naphthalene and anthracene (chemically pure grade) were taken. Additives were introduced into a preheated tar to $343 \mathrm{~K}$, stirred at laboratory homogenizer at minimum speed and kept to measured temperature.

The correlation coefficients (function "CORREL" in Excel format) were used to determine the relationship between empirical and obtained data groups.
In addition, the average relative deviation of the calculated values from experimental data was calculated by varying the coefficients $a, b, c$ in the Vogel equation for the minimal value $\delta$ :

$$
\delta=\frac{1}{n} \sum_{n}\left|\frac{\eta_{e}-\eta_{t}}{\eta_{e}}\right|
$$

where $\eta_{e}$ - the experimentally obtained value of viscosity, $\mathrm{cP} ; \eta_{t}$ - the estimated value of viscosity, $\mathrm{cP} ; n$ - number of experimental values.

The correlation coefficient reflects the "type" of functional dependence, and the convergence of the results determined by the mean of relative deviation. Therefore, a double assessment of suitability of the calculated and experimental data was made. New models of temperature dependencies of viscosity at various additives can be considered adequate for the values of correlation coefficients above 0.95 and average relative deviation of not greater than 0.05 , which is acceptable for engineering calculations of chemical and technological processes in the majority of cases.

\section{Results and Discussion}

\subsection{Tar Viscosity with Additives}

The results of measurement are shown in Tables 2 and 3.

Table 1

Quality of tar from primary gas cooler

\begin{tabular}{|c|c|c|c|c|}
\hline $\begin{array}{c}\text { Density at 293 K, } \\
\mathrm{g} / \mathrm{cm}^{3}\end{array}$ & $\begin{array}{c}\text { Water content, } \\
\mathrm{wt} \%\end{array}$ & $\begin{array}{c}\text { Toluene insoluble, } \\
\text { water free, } \mathrm{wt} \%\end{array}$ & $\begin{array}{c}\text { Quinoline insoluble, water } \\
\text { free, } \mathrm{wt} \%\end{array}$ & $\begin{array}{c}\text { Ash content, } \\
\text { water free, } \mathrm{wt} \%\end{array}$ \\
\hline 1188 & 3.0 & 9.2 & 6.8 & 0.16 \\
\hline
\end{tabular}

Table 2

Influence of the temperature on coal tar viscosity $(\mathrm{cP})$ with the addition of naphthalene

\begin{tabular}{|c|c|c|c|c|}
\hline \multirow{2}{*}{ Naphthalene additive, g/100 g of tar } & \multicolumn{4}{|c|}{ Temperature, K } \\
\cline { 2 - 5 } & 313 & 323 & 333 & 343 \\
\hline 0 & 69.55 & 37.01 & 24.35 & 16.75 \\
\hline 3 & 64.60 & 33.03 & 23.60 & 16.35 \\
\hline 5 & 53.45 & 28.00 & 20.09 & 15.80 \\
\hline 10 & 39.60 & 23.10 & 18.75 & 14.75 \\
\hline 15 & 44.20 & 21.00 & 14.75 & 13.79 \\
\hline 20 & 20.71 & 16.02 & 12.00 & 8.38 \\
\hline
\end{tabular}

Table 3

Influence of the temperature on coal tar viscosity $(\mathrm{cP})$ with the addition of anthracene

\begin{tabular}{|c|c|c|c|c|}
\hline \multirow{2}{*}{ Anthracene additive, $\mathrm{g} / 100 \mathrm{~g}$ of tar } & \multicolumn{4}{|c|}{ Temperature, K } \\
\cline { 2 - 5 } & 323 & 333 & 343 & 353 \\
\hline 0 & 43.00 & 25.00 & 16.25 & 12.00 \\
\hline 5 & 57.50 & 26.0 & 18.30 & 16.00 \\
\hline 15 & 83.80 & 50.00 & 29.80 & 25.00 \\
\hline
\end{tabular}


It can be seen from the tables that as the temperature increases the viscosity of the tar without the addition begin to fall very quickly, and then more slowly, which is typical of coal tar and petroleum derived liquids. With naphthalene addition tar viscosity is reduced and the slope of the curve of viscosity temperature dependence at $323-333 \mathrm{~K}$ is less than without additives. This type of curves is characteristic for light oils and tars. The addition of anthracene, on the contrary, increases the viscosity of the system and the slope of the curves at 323-333 K with anthracene adding, which is characteristic for heavy oils and tars. It can be assumed that the cause of increased viscosity of the tar is the presence of condensed polynuclear aromatics.

The addition of naphthalene causes disaggregation of existing tar flow units, and anthracene, apparently regulates the structure. It is known that the temperature dependence of the viscosity is most pronounced at low temperatures, which involves the dissolution of organized molecular structures such as aggregates of large molecules [4].

In this low-temperature region additives have the greatest impact on rheology. The tar contains large molecular aggregates that are responsible for increasing viscosity at low temperatures and expressed close relationship with temperature. The reduction in viscosity is a result of the gradual destruction of the structure of the system.

\subsection{Vogel Equation Tar Viscosity Estimation}

The abundance of the set of equations describing the dependence of viscosity on temperature shows a lack of consensus on the rheology of coal tar. Thus, the same system can be described by several formulas, and vice versa, different systems can be acceptably described by the same equation. Assessment of the temperature dependence of the viscosity obtained values can be done by empirical dependencies. One of the ways to predict the viscosity of the oils is Vogel formula [5]:

$$
\eta=a \cdot e^{\frac{b}{T-c}}
$$

where $\eta$-dynamic viscosity; $T$ - temperature, $\mathrm{K} ; a, b, c$ constants of the equation.

Vogel equation is considered one of the most accurate for engineering calculations. The form of the equation is comparable to the well-known Antoine equation to calculate the vapor pressure. Vogel equation constants are determined experimentally, the constant " $a$ " has the physical meaning of "original" viscosity of the system, which is a viscosity of the liquid at an infinitely high temperature. Constant " $b$ " to some extent characterizes the rate of change of viscosity with respect to temperature.
The results of calculation of the coefficients for Vogel equation are presented in Tables 4-5.

Fitting of the most "appropriate" values of $a, b, c$ with additives increasing leads to distortion of physical sense of coefficients, since the best results with increasing naphthalene additive was obtained by antiphase change of $a$ and $b$ coefficients, at the same time the coefficients $a$ and $c$ changed in-phase. If we consider the results of coefficients fitting across one line, i.e. in-phase, the following trends are observed:

- for the coefficient $a$ : as naphthalene additive increases the viscosity of the liquid at infinite temperature also increase;

- for the coefficient $b$ : as naphthalene additive increases the temperature dependence reduces;

- for the coefficient $c$ : as naphthalene additive increases apparent "pour point" also increase.

\subsection{Walter Equation Tar Viscosity Estimation}

The temperature dependence of the coal tar viscosity can be estimated by the Walter equation in logarithmic form [6], which is included in the methodology for viscosity determining on ASTM D341:

$$
\log \log \eta=K_{1}-K_{2} \log T
$$

where $K_{1}$ and $K_{2}$ - constants of equation; $\eta$ - viscosity, cP; $T$ - temperature, $\mathrm{K}$.

Eq. (3) is a modified Walter equation in logarithmic form, and is characterized by the absence factor of 0.8 in the left part:

$$
\log \log (\eta+0.8)=K_{1}-K_{2} \log T
$$

The results of fitting of the Walter equation constants for the obtained viscosity measurements are shown in Tables 6-7.

\subsection{Cornelissen-W aterman Equation Tar Viscosity Estimation}

Equation of Cornelissen-Waterman is used to assess, in particular, the rheological properties of coal tar pitch and coal tar [6]:

$$
\log \eta=A T^{-5}+B
$$

where $A$ and $B$ - constants of equation; $\eta$ - viscosity, cP; $T$ - temperature, $\mathrm{K}$.

The results of fitting of the Cornelissen-Waterman equation constants for the obtained viscosity measurements are shown in Tables 8-9.

With the anthracene addition of $15 \mathrm{~g} / 100 \mathrm{~g}$, coal tar precipitate was probably formed because the curve of Cornelissen-Waterman in this case only has a distinctive look, but does not adequately describe the experimental results obtained. 
Values of the Vogel equation coefficients for primary cooler's coal tar with naphthalene additives

\begin{tabular}{|c|c|c|c|c|c|}
\hline Naphthalene additive, $\mathrm{g} / 100 \mathrm{~g}$ of tar & $a$ & $b$ & $c$ & Correlation coefficients & Average relative deviation, $\delta$ \\
\hline 0 & 3.56 & 104.25 & 278 & 0.999 & 0.029 \\
\hline 3 & 1.69 & 175 & 265 & 0.999 & 0.034 \\
\hline 5 & 3.75 & 82 & 282 & 1.000 & 0.045 \\
\hline 10 & 2.3 & 150 & 260 & 0.993 & 0.047 \\
\hline 15 & 4.5 & 52 & 290 & 0.997 & 0.053 \\
\hline 20 & 2.2 & 140 & 250.5 & 0.987 & 0.062 \\
\hline
\end{tabular}

Table 5

Values of the Vogel equation coefficients for primary cooler's coal tar with anthracene additives

\begin{tabular}{|c|c|c|c|c|c|}
\hline Anthracene additive, g/100 g of tar & $a$ & $b$ & $c$ & Correlation coefficients & Average relative deviation, $\delta$ \\
\hline 0 & 2.795 & 104.88 & 284.65 & 0.999 & 0.035 \\
\hline 5 & 12.05 & 14.06 & 314 & 0.999 & 0.045 \\
\hline 15 & 1.18 & 290 & 255 & 0.998 & 0.047 \\
\hline
\end{tabular}

Values of the Walter equation coefficients for primary cooler's coal tar with naphthalene additives

\begin{tabular}{|c|c|c|c|c|}
\hline Naphthalene additive, g/100 g of tar & $K_{1}$ & $K_{2}$ & Correlation coefficients & Average relative deviation, $\delta$ \\
\hline 0 & 12.751 & 5.0029 & 0.999 & 0.055 \\
\hline 3 & 12.485 & 4.9 & 0.996 & 0.074 \\
\hline 5 & 11.715 & 4.6 & 0.992 & 0.072 \\
\hline 10 & 10.184 & 4 & 0.987 & 0.081 \\
\hline 15 & 13.438 & 5.3 & 0.981 & 0.114 \\
\hline 20 & 12.88 & 5.1 & 0.981 & 0.114 \\
\hline
\end{tabular}

Values of the Walter equation coefficients for primary cooler's coal tar with anthracene additives

\begin{tabular}{|c|c|c|c|c|}
\hline Anthracene additive, g/100 g of tar & $K_{1}$ & $K_{2}$ & Correlation coefficients & Average relative deviation, $\delta$ \\
\hline 0 & 12.77 & 5.0029 & 1.000 & 0.035 \\
\hline 5 & 14.2973 & 5.6 & 0.985 & 0.112 \\
\hline 15 & 12.59 & 4.9 & 0.998 & 0.094 \\
\hline
\end{tabular}

Values of the Cornelissen-Waterman equation coefficients

for primary cooler's coal tar with naphthalene additives

\begin{tabular}{|c|c|c|c|c|}
\hline Naphthalene additive, $\mathrm{g} / 100 \mathrm{~g}$ of $\operatorname{tar}$ & $A$ & $B$ & Correlation coefficients & Average relative deviation, $\delta$ \\
\hline 0 & $5.012 \cdot 10^{12}$ & 0.162 & 0.999 & 0.022 \\
\hline 3 & $5.623 \cdot 10^{12}$ & -0.057 & 0.997 & 0.092 \\
\hline 5 & $4.982 \cdot 10^{12}$ & 0.07 & 0.993 & 0.075 \\
\hline 10 & $4.891 \cdot 10^{12}$ & -0.029 & 0.993 & 0.136 \\
\hline 15 & $6.50 \cdot 10^{12}$ & -0.52 & 0.988 & 0.179 \\
\hline 20 & $2.50 \cdot 10^{12}$ & 0.48 & 0.992 & 0.069 \\
\hline
\end{tabular}

Table 9

Values of the Cornelissen-Waterman equation coefficients for primary cooler's coal tar with anthracene additives

\begin{tabular}{|c|c|c|c|c|}
\hline Anthracene additive, $\mathrm{g} / 100 \mathrm{~g}$ of $\operatorname{tar}$ & $A$ & $B$ & Correlation coefficients & Average relative deviation, $\delta$ \\
\hline 0 & $5.24807 \cdot 10^{12}$ & 0.13 & 0.999 & 0.033 \\
\hline 5 & $6.30957 \cdot 10^{12}$ & -0.04 & 0.982 & 0.122 \\
\hline 15 & $1.11 \cdot 10^{13}$ & -2.2 & 0.991 & 0.939 \\
\hline
\end{tabular}




\subsection{Coefficients of Equations Evaluation and Activation Energy of Viscous Flow}

Analysis of the mean relative deviation indicates that all received correlations on the basis of available empirical functions satisfactorily describe the experimental data in the absence of additives, or in the range of small additives values (Fig. 1). With the growth of additives mass, accuracy of empirical relationships is reduced; the most applicable function in the presence of an additive is the Vogel equation while in the absence of additives - Cornelissen-Waterman equation.

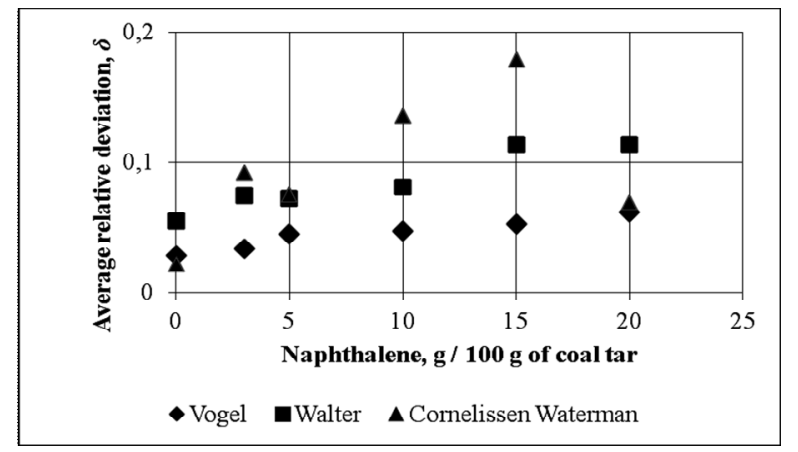

Fig. 1. The average relative deviation of experimental data from the calculated data obtained by the equations of Vogel, Walter and Cornelissen-Waterman for naphthalene

This data shows the effect of additives on the thermal behavior of the viscosity that differs from the empirical relationships. Thus, the addition input alters the established nature of the interaction of macromolecules and dispersed structures in coal tar.

In the case of anthracene additives anomaly of viscosity with decreasing temperature was observed, due to the formation of the spatial structural lattices of particles of an inner phase consisting of crystals, which entails, in this case, the impossibility of matching the coefficients of Vogel, Walter and Cornelissen-Waterman equations in the investigated temperature range. The addition of naphthalene, on the other hand, causes a decrease in viscosity due to dissolution and disaggregation of existing supramolecular structure of coal tar from primary cooler.
It is known that the constants $K_{2}$ in the modified Walter Equation and $B$ in the Cornelissen-Waterman equations are the measure of the temperature dependence regardless to the liquid level of viscosity [6].

Data analysis of the Tables 4, 6, 8 showed that the obtained empirical constants of Walter $\left(K_{2}\right)$ and Cornelissen-Waterman $(B)$ equations were at minimal values in the range of naphthalene additives by $10-15 \mathrm{~g} / 100 \mathrm{~g}$ of tar. Perhaps it is due to the energy state of the system.

The energy states of complex chemical or physical systems are permissible to assess as their empirical (effective) values, or as the activation energy of viscous flow $[7,8]$ :

$$
E_{a}=R \times \ln \left(\mu_{1} / \mu_{2}\right) \times\left(\frac{1}{T_{1}}-\frac{1}{T_{2}}\right)
$$

where $E_{a}$ - activation energy, $\mathrm{J} / \mathrm{mol} ; R$ - universal gas constant, J/mol.K; $\mu_{1}-$ viscosity $(\mathrm{cP})$ at temperature $T_{1}(\mathrm{~K})$.

Tables 10 and 11 show the results of calculation of the activation energy with the addition of naphthalene and anthracene.

The minimum of activation energy of viscous flow corresponds to the magnitude of the additive at which the unbundling and the dissolution of the existing structures take place. In such systems, the speed of movement of each particle is less dependent on the position and speed of other particles. The increase in the value of $E_{a}$ means transformation in a more structured system state.

According to Table 10 less structured systems correspond to the naphthalene additive of $15 \mathrm{~g} / 100 \mathrm{~g}$ of tar during the system transition from 333 to $343 \mathrm{~K}$. In our opinion, activation energy minimum, coinciding with a decline of degree of the temperature dependence of the tar viscosity (constants $K_{2}$ and $B$ ), is associated with the optimal amount of naphthalene contributed to the dissolution of the structural units of flow. Further increase of the additive causes the formation of new localized spatial structures involving addition of naphthalene, although the viscosity of the system at the same time continues to drop with increasing the amount of the dispersion phase. The practical importance for primary cooler washing process has $E_{a}$ minimums in the temperature range of $313-333 \mathrm{~K}$ with the addition of naphthalene $15 \mathrm{~g} / 100 \mathrm{~g}$ of tar.

Table 10

The activation energy of viscous flow, $E_{a}, \mathrm{~kJ} / \mathrm{mol}$, with the addition of naphthalene

\begin{tabular}{|c|c|c|c|}
\hline \multirow{2}{*}{ Naphthalene additive, $\mathrm{g} / 100 \mathrm{~g}$ of tar } & \multicolumn{3}{|c|}{ Temperature range, $\mathrm{K}$} \\
\cline { 2 - 4 } & $313-323$ & $323-333$ & $333-343$ \\
\hline 0 & 53.0 & 37.4 & 35.5 \\
\hline 3 & 56.5 & 30.0 & 34.9 \\
\hline 5 & 54.3 & 29.7 & 22.8 \\
\hline 10 & 45.7 & 18.3 & 22.8 \\
\hline 15 & 62.6 & 31.6 & 6.4 \\
\hline 20 & 21.7 & 25.7 & 34.1 \\
\hline
\end{tabular}


The activation energy of viscous flow, $E_{a}, \mathrm{~kJ} / \mathrm{mol}$, with the addition of anthracene

\begin{tabular}{|c|c|c|c|}
\hline \multirow{2}{*}{ Anthracene additive, $\mathrm{g} / 100 \mathrm{~g}$ of $\mathrm{tar}$} & \multicolumn{3}{|c|}{ Temperature range, $\mathrm{K}$} \\
\cline { 2 - 4 } & $323-333$ & $333-343$ & $343-353$ \\
\hline 0 & 48.5 & 40.9 & 30.5 \\
\hline 5 & 71.0 & 33.6 & 13.2 \\
\hline 15 & 46.2 & 49.0 & 17.8 \\
\hline
\end{tabular}

A small addition of anthracene in the 323-333 K range corresponds to the formation of a structured system; the lowest activation energy of viscous flow occurs at the temperature transition from 343 to $353 \mathrm{~K}$, which can only take place when the tar was heated just before primary cooler washing.

\section{Conclusions}

Cooling and condensation of coking volatile products superposes with coal tar washing of apparatus gas space, and as increasing and lowering of the tar viscosity take place due to the dissolution of nonsubstituted aromatic compounds. For the most representative compounds - naphthalene and anthracene coefficients of Vogel equation were adapted, that adequately described the temperature dependence of the viscosity in the range of 313-353 $\mathrm{K}$ and additives mass up to $20 \mathrm{~g} / 100 \mathrm{~g}$ of coal tar. The empirical equations of Walter and Cornelissen-Waterman in the same range may be used for qualitative assessment. Thus, the constant $K_{2}$ and $B$ have a minimum value with the addition of naphthalene in the amount of $10-15 \mathrm{~g} / 100 \mathrm{~g}$ of coal tar.

Based on the assessment of the energy state of the system it was found that a decrease in the activation energy of viscous flow took place in the temperature range of $333-343 \mathrm{~K}$ with the addition of naphthalene $15 \mathrm{~g} / 100 \mathrm{~g}$ of coal tar. The tar with the naphthalene additive has improved flow properties with destroyed structured units and increased volume of the dispersion phase. These conditions are maintained in the upper sections of the primary gas cooler, and temperature interval corresponds to the point of condensation of almost full amount of tar.

Quantitative relationship of tar lowering viscosity when dissolving naphthalene was estimated, that may be used, for example, to increase fluidity of more viscous tar from gas collecting relative to the tar pyrolysis degree. Dissolving tar deposits with a high content of anthracene worsens the rheological properties of the tar and makes the washing cooler gas space inefficient.

When cooling coking volatile products below the temperature range of $333-343 \mathrm{~K}$ tar condensation is complete, and at further lowering of the temperature the dependence of the viscosity on the amount of dissolving the additive increases.

High temperature washing tar heating and higher content of naphthalene contribute to anthracene formations elimination from the washing liquid.

\section{Acknowledgements}

The authors express their gratitude to the staff of the central plant laboratory and workshop of chemical coking products recovery PJSC "AKHZ"

\section{References}

[1] Kovalev E.: Ulavlivanie i Pererabotka Khimicheskih Produktov Koksovaniya, Tom 3. Izdatelsky dom «INZHEK», Kharkov 2009.

[2] Wright K.: Coke Oven Gas Treatment: Tar, Liquor, Ammonia. Coke-Oven Managers' Association, Sheffield 2004.

[3] Chen Y., Zhou Y., Li C. et al.: Pat. CN202279802, Publ. Jun. 20, 2012.

[4] Barnes H., Hutton J. and Walter K.: An Introduction to Rheology. Elsevier, Amsterdam 1989.

[5] Cameron A. and Ettles C.: Basic Lubrication Theory. Ellis Horwood Ltd., London 1981.

[6] Wood L. and Downer M.: J. Appl. Chem., 1965, 8, 431.

[7] Pyshyev S., Grytsenko Y., Bilushchak H. et al.: Petrol. Coal, 2015, 57, 4.

[8] Krasulia M. and Shustikov V.: Khimia Tverdogo Topliva, 1991, 3, 77 .

Received: April 08, 2016 / Revised: M ay 26, 2016 /

Accepted: December 12, 2016

\section{В'ЯЗКІСТЬ КАМ'ЯНОВУГІЛЬНОЇ СМОЛИ ПРИ РОЗЧИНЕННІ ВІДКЛАДЕНЬ КОКСОВОГО ГАЗУ}

Анотація. Отримані дані про в'язкість смоли при розчиненні голоядерних ароматичних сполук (нафталену $i$ антрацену). Підібрані коефіиієнти наявних емпіричних рівнянь в'язкості в залежності від добавок нафталену і антрачену. При штучному внесенні добавок в смолу досліджені реологічні властивості на віскозиметрі Брукфільда. Встановлено аномальність значень енергії активації в'язкісної течії при добавиі нафталену, при якій також спостерігаються мінімальні значення константи $K_{2}$ рівняння Вальтера та константи $B$ рівняння Корнеліссен-Ватермана. На цій підставі рекомендовані температурні інтервали та оптимальна кількість нафталену у смолі з покраменими реологічними характеристиками.

Ключові слова: кам'яновугільна смола, газозбірник, первинний холодильник, в'язкість. 